\title{
The effect of cracks on the bearing capacity of reinforced concrete slabs
}

\author{
Vladimir Agapov ${ }^{*}$ \\ Moscow State University of Civil Engineering, Yaroslavskoye Shosse, 26, Moscow, 129337, Russia
}

\begin{abstract}
Cracks occur in reinforced concrete slabs for two reasons - due to increased operational loads and due to manufacturing and installation defects. When cracks are detected, the question arises about the residual bearing capacity of the slab and the need of its strengthening. To solve this problem by calculation, it is necessary to take into account physical nonlinearity. An algorithm for the calculation by the finite element method is proposed. The main feature of the algorithm is the use of multilayered finite elements, which allows modeling the cracks by specifying the corresponding material characteristics of those layers which the crack passes through. A method for determining the bearing capacity of a slab with cracks after its reinforcement with composite fabrics is also considered. An example of the study of the stress-strain state of a reinforced concrete slab with cracks by the proposed method is given. The implementation of the algorithm in the PRINS program is described and the possibility of using this program for solving practical problems is discussed.
\end{abstract}

\section{Introduction}

Successes in the production of building materials [1-5], on the one hand, and in the technology of building production [6,7] - on the other, provide the possibility of reconstruction and repair of reinforced concrete structures without their dismantling. At that, steel reinforcement, cement-sand mixtures and composite materials based on carbon fibres are used for the strengthening of reinforced concrete structures [8-10]. In particular, in the repair of reinforced concrete slabs, shells, beams and columns, composite tapes and fabrics with unidirectional and bidirectional properties are used [11-12]. Recommendations for the repair and strengthening of reinforced concrete structures developed by various departments [8-12] imply a strength analysis of the objects under consideration both before and after the works have been performed. A feature of such studies is a change in the design model of the structure as a result of repair or reconstruction [13], as well as the presence of initial stresses and strains if reinforcement works are carried out on retention of the entire operational load or part of it. This requires the development of special software or making appropriate additions to existing programs. The method of the stress-strain state analysis of reinforced concrete slabs in which cracks arise during long-term operation and the implementation of this method in the computer program PRINS are described in this paper.

\footnotetext{
* Corresponding author: agapovpb@mail.ru
} 


\section{Methods}

To determine the bearing capacity of reinforced concrete slabs the algorithm described in the previously published works of the author is used in the PRINS program (see, for example, $[14,15])$. The main features of this algorithm are as follows.

The calculation of physically nonlinear structures is carried out by the incremental/iterative method using the equation:

$$
\mathbf{K}_{\mathbf{N L}} \Delta \mathbf{u}=\Delta \mathbf{P}
$$

where $\mathbf{K}_{\mathbf{N L}}$ is the total nonlinear stiffness matrix, connecting the increments of the nodal forces and displacements, $\Delta \mathbf{u}$ and $\mathbf{\Delta} \mathbf{P}$ are the increments of the nodal displacements and the nodal forces of the finite element model, respectively.

The matrix $\mathbf{K}_{\mathbf{N L}}$ is represented as:

$$
\mathrm{K}_{\mathrm{NL}}=\mathrm{K}_{\mathbf{0}}+\Delta \mathrm{K}
$$

After substitution (2) in (1), we get

$$
\left(\mathbf{K}_{0}+\Delta \mathbf{K}\right) \Delta \mathbf{u}=\Delta \mathbf{P}
$$

Equotion (2) is solved by iterative method:

$$
K_{0} \Delta u_{i}=\Delta P-\Delta K_{i-1} \Delta u_{i-1}
$$

were $i$-iteration number.

At the end of the iterative process, the total values of displacements and stresses at the end of the loading step are found by formulas:

$$
\mathbf{u}=\mathbf{u}_{0}+\Delta \mathbf{u} ; \sigma=\sigma_{0}+\Delta \sigma
$$

The stress increments are found by formula:

$$
\Delta \boldsymbol{\sigma}=\mathrm{C}_{\mathrm{ep}} \Delta \boldsymbol{\varepsilon} .
$$

where $\mathbf{C}_{\mathrm{ep}}$ is the elasto-plastic matrix of material characteristics [14 ].

At each step of loading, the stress state is analyzed and, when plastic strains and cracks occur, the stresses are corrected taking into account the adopted deformation diagrams of the materials. This requires the carrying out of the process of equilibration of the structure. The equilibrium iterations is performed in the program PRINS in accordance with the formula:

$$
\mathbf{K}_{\mathbf{j}}^{\mathrm{i}} \Delta \mathbf{u}_{\mathbf{j}}^{\mathrm{i}}=\mathbf{P}_{\mathbf{j}}-\mathbf{F}_{\mathbf{j}}^{\mathbf{i}-1}
$$

where $\mathbf{K}$ - tangent stiffness matrix, $\Delta \mathbf{u}$ - nodal displacements vector, $\mathbf{P}$ - vector of the externally applied nodal loads, $\mathbf{F}$ - vector of nodal point forces that are equivalent to the element stresses, $\mathrm{j}$ - step number, $\mathrm{i}$-iteration number. 
When using formulas (1-7), the calculation is carried out with preservation of the design scheme. To solve the problem posed in this article, the algorithm implemented earlier has been updated in accordance with the flowchart shown in figure 1.

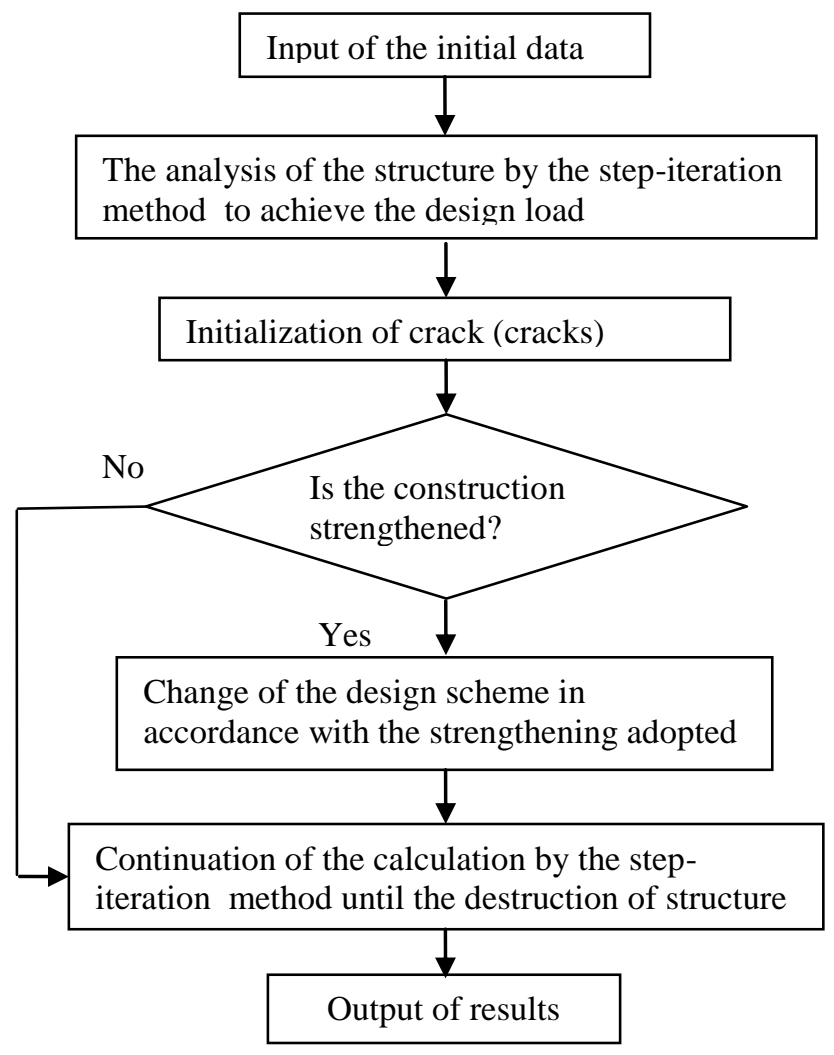

Fig. 1. Flow diagram of the algorithm for calculating the slabs with cracks arising at the operation stage.

Cracks are initialized in the program PRINS by specifying the corresponding characteristics of the stress-strain state of concrete layers containing cracks, and the design scheme is changed by replacing the original material package with the enhanced one.

\section{Results}

To illustrate the developed technique, a square symply supported reinforced concrete slab was investigated with the following initial data: slab size $8 \times 8 \mathrm{~m}$, slab thickness $25 \mathrm{~cm}$; concrete of class $\mathrm{B} 30$, normative compressive strength of $22 \mathrm{MPa}$, normative tension strength of $1.75 \mathrm{MPa}$, elastic modulus $\mathrm{E}=3.25 \times 10^{7} \mathrm{MPa}$, Poisson's ratio $\mu=0.2$; reinforcement of class A500, standard resistance $500 \mathrm{MPa}$, Poisson's ratio $\mu=0.3$; the reinforcement was made on the load $q=20 \mathrm{kPa}$, while 4 rods with a diameter of $14 \mathrm{~mm}$ per linear meter of slab length were taken (spacing of reinforcement equal to $250 \mathrm{~mm}$ ); to strengthen the slab, a bidirectional composite fabric with a tensile strength of $4.9 \mathrm{GPa}$, elastic modulus of $245 \mathrm{GPa}$ and a residual strain of $1.8 \%$ was used ; the slab was divided in thickness into 32 layers; two packages of materials - the original (package number 1) and 
repair (package number 2) were used in the calculation.The characteristics of layers are shown in Tables 1 and 2.

Table 1. The package №1 of the layer characteristics.

\begin{tabular}{|c|c|l|}
\hline $\begin{array}{c}\text { The layer } \\
\text { number }\end{array}$ & $\begin{array}{c}\text { Thickness, } \\
\mathrm{cm}\end{array}$ & Materials \\
\hline 1 & 0 & Concrete \\
\hline $2-22$ & 1 & Concrete \\
\hline 23 & 0.272 & Concrete \\
\hline 24 & 0.228 & Steel, $\alpha=0$ \\
\hline 25 & 0.228 & Steel, $\alpha=90$ \\
\hline 26 & 0.272 & Concrete \\
\hline $27-29$ & 1 & Concrete \\
\hline 30 & 0.1 & $\begin{array}{l}\text { Material with reduced } \\
\text { elastic modulus }\end{array}$ \\
\hline 31 & 0.1 & $\begin{array}{l}\text { Material with reduced } \\
\text { elastic modulus }\end{array}$ \\
\hline 32 & 0 & Concrete \\
\hline
\end{tabular}

Table 2. The package №2 of the layer characteristics.

\begin{tabular}{|c|c|l|}
\hline $\begin{array}{c}\text { The layer } \\
\text { number }\end{array}$ & $\begin{array}{c}\text { Thickness, } \\
\mathrm{cm}\end{array}$ & Materials \\
\hline 1 & 0 & Concrete \\
\hline $2-22$ & 1 & Concrete \\
\hline 23 & 0.272 & Concrete \\
\hline 24 & 0.228 & Сталь, $\alpha=0$ \\
\hline 25 & 0.228 & Сталь $\alpha=90$ \\
\hline 26 & 0.272 & Concrete \\
\hline $27-29$ & 1 & Concrete \\
\hline 30 & 0.1 & Composite fabric \\
\hline 31 & 0.1 & Composite fabric \\
\hline 32 & 0 & Concrete \\
\hline
\end{tabular}

The angle $\alpha$ in the tables 1 and 2 is the steel reinforcement orientation angle. The layers 1 and 32 are fictitious. Fictitious layers are introduced to enable the output of the stresses and cracks on the lower and upper surfaces in the postprocessor. The layers 30 and 31 in the package № 1are also fictitious with the fictitious material having a modulus of elasticity several orders of magnitude lower than the modulus of elasticity of concrete and steel reinforcement. These layers have almost no effect on the operation of the slab in its original state. They are needed for the transition from one calculation scheme to another.

The design scheme of the slab with the numbering of elements is shown in figure 2 .

At the first stage, the slab was calculated by a step-iteration method up to destruction according to the PRINS program. The maximum value of the deflection under load $q=20$ $\mathrm{kPa}$ was equal to $2.04 \mathrm{~cm}$, which is less than the allowable value of $L / 200=800 / 200=4$ $\mathrm{cm}$. Figure 3 shows the first cracks on the lower surface under a load of $8 \mathrm{kPa}$, and Figure 4 shows cracks with a nominal load of $20 \mathrm{kPa}$. 


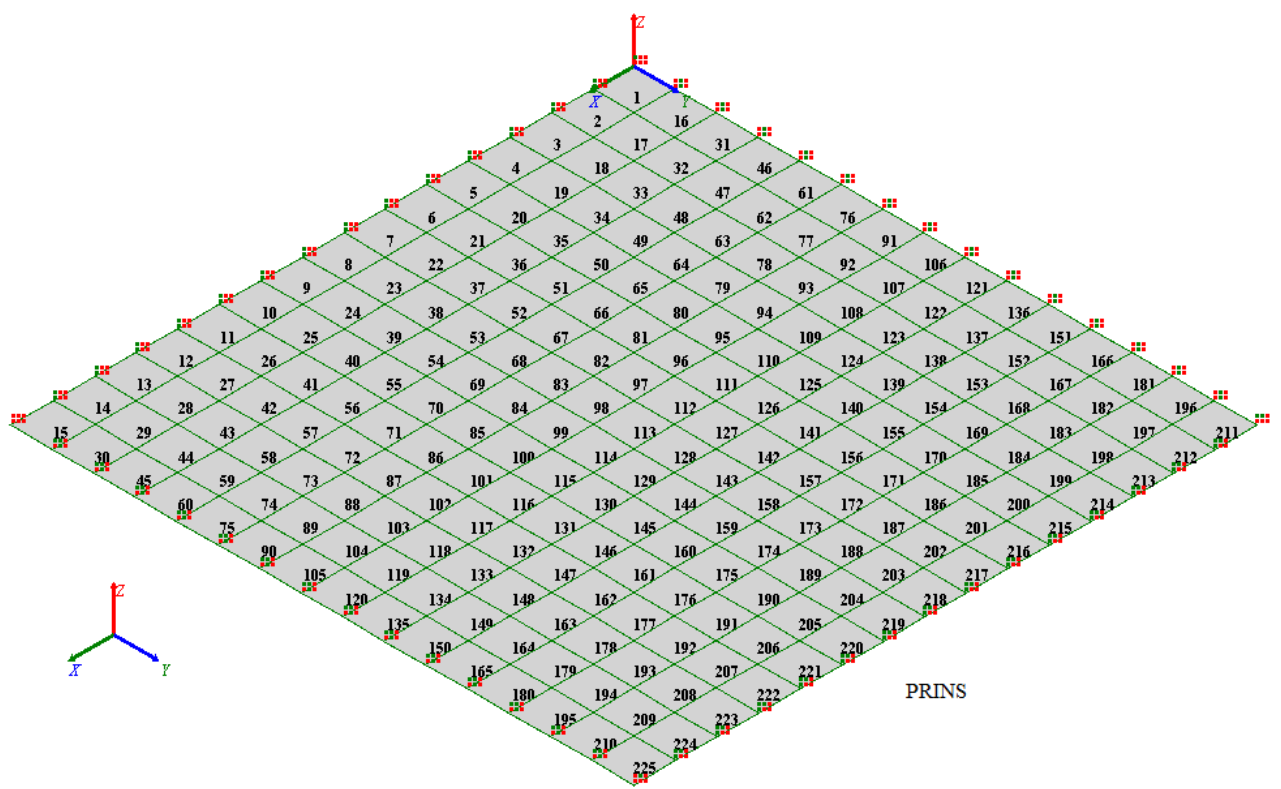

Fig. 2. The design sheme of slab.

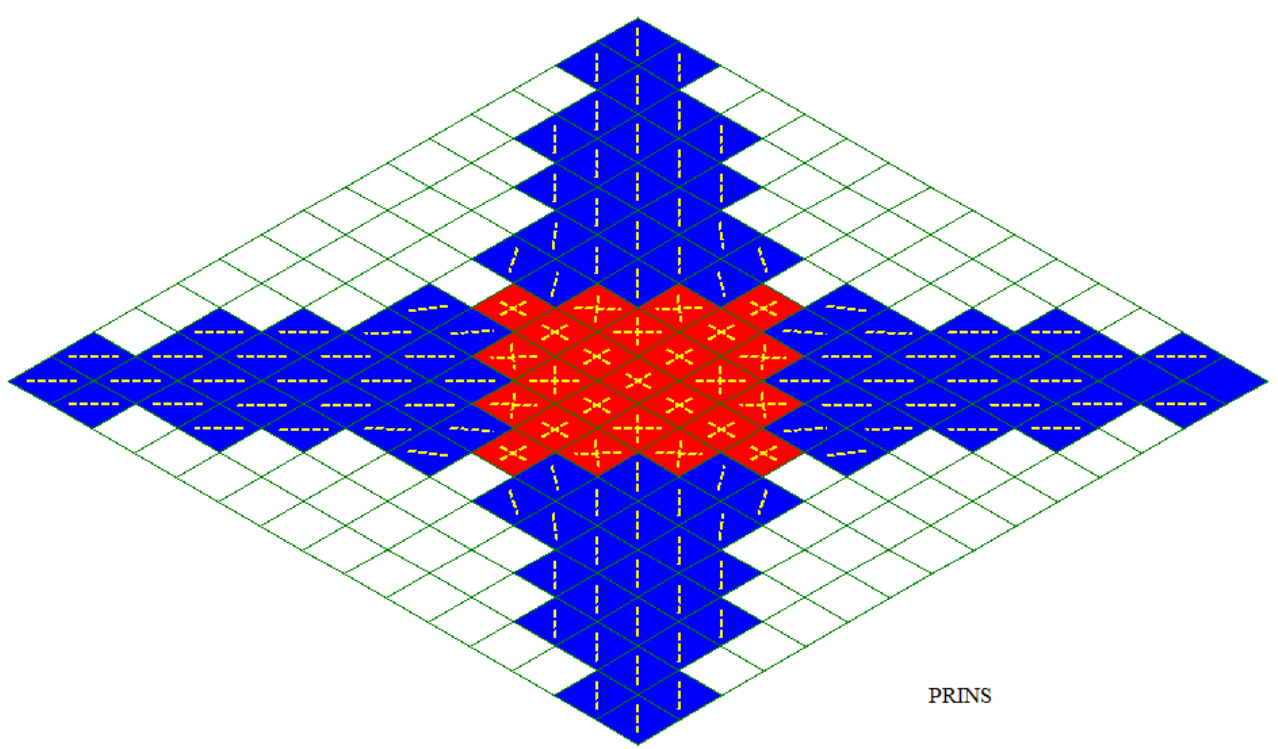

Fig. 3. The first cracks under load of $8 \mathrm{kPa}$.

As can be seen from figures 3 and 4, two mutually perpendicular cracks occur in the central region of the plate, and their directions are parallel to the outer contour of the plate. In the remaining regions, one crack arises at each point, and its direction depends on the ratio between the shear and normal stresses. Closer to the corners of the slab, the direction of the cracks approaches 45 degrees with respect to the external contour. 


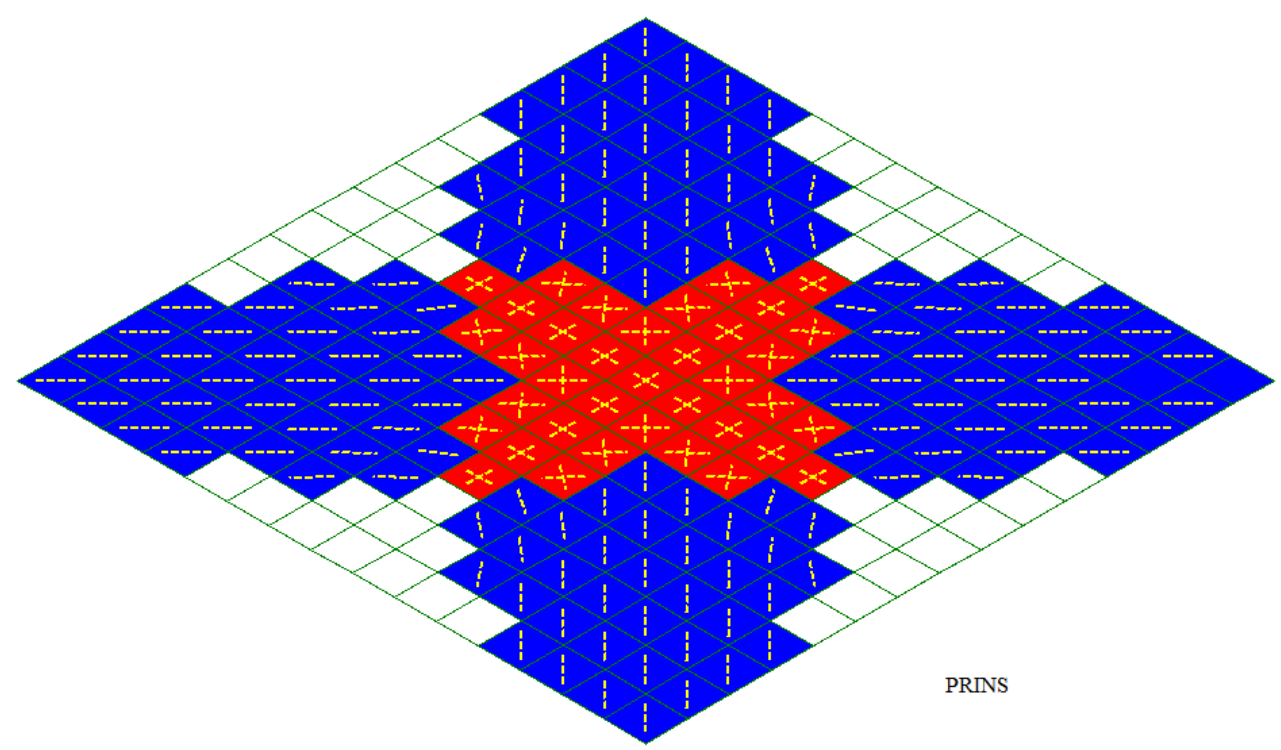

Fig. 4. The cracks under load of $20 \mathrm{kPa}$.

The crack opening at a nominal load of $20 \mathrm{kPa}$ was found taking into account the recommendations of building acts [16] according to the formula:

$$
a_{c r c}=\varphi_{1} \varphi_{2} \varphi_{3} \psi_{s} \frac{\sigma_{s}}{E_{s}} l_{s}
$$

where the coefficients $\varphi_{1}, \varphi_{2}$ and $\varphi_{3}$ are determined by the regulatory documents depending on the source data, $\psi_{s}$ - the coefficient taking into account the ununiform distribution of the strains of the tensile reinforcement between the cracks, $\sigma_{s}$ - the stress in the reinforcement, $E_{s}$-the modulus of elasticity of the reinforcement, $l_{s}-$ the basic distance between the cracks.

The coefficient $\psi_{s}$ is assumed to be one if the condition is met:

$$
a_{c r c} \leq a_{c r c, u l t}
$$

where $a_{c r c, u l t}$ - the maximum allowable width of crack opening.

Provided the safety of the reinforcement is maintained, the value $a_{c r c, u l t}$ is assumed to be $0.3 \mathrm{~mm}$ with prolonged opening of the cracks, and $0.4 \mathrm{~mm}$ with a short opening.

If the condition (9) is not satisfied, the value of $\psi_{s}$ is calculated by the formula:

$$
\psi_{s}=1-0,8 \frac{\sigma_{s, c r c}}{\sigma_{s}}
$$

where $\sigma_{s, c r c}$ is the stress in the longitudinal tensioned reinforcement in a section with a crack immediately after the formation of a crack. 
The value of the base distance between cracks is determined by the formula:

$$
l_{s}=0,5 \frac{A_{b t}}{A_{s}} d_{s},
$$

where $A_{b t}$-the cross-sectional area of the stretched concrete, $A_{s}$-the cross-sectional area of the stretched reinforcement, $d_{s}$ - the diameter of the reinforcement. For elements with a cross-section height of not more than $1 \mathrm{~m}$, the value $l_{s}$ is taken not less than $10 d_{s}$ and 10 sm and not more than $40 d_{s}$ and $40 \mathrm{~cm}$.

In our case $\varphi_{1}=1,4$ (a prolonged load action is considered), $\varphi_{2}=0,5$ (for reinforcement of class A500), $\varphi_{2}=1$ in bending, $\psi_{s}=1$.

The stress in the reinforcement at the load of $20 \mathrm{kPa}$ was $79500 \mathrm{kPa}$, and the height of the stretched zone was equal to $16 \mathrm{~cm}$. The thickness of the equivalent reinforcement layer in the adopted design scheme was equal to $0.228 \mathrm{~cm}$. With these data $l_{s}=0,5 \frac{16}{0,228} 1,4 \mathrm{~cm}=49,12 \mathrm{~cm}$. Let's accept $l_{s}=40 \mathrm{~cm}$. The width of the crack opening in the most dangerous section is equal to $a_{c r c}=1,4 \times 0,5 \times 1 \times 1 \times \frac{79500}{2 \times 10^{8}} 400 \mathrm{~mm}=0,111 \mathrm{~mm}<0,3 \mathrm{~mm}$.

In figure 5 the load-displacemen curve is shown. As can be seen from figure 5 , the loadbearing capacity of the reinforced concrete slab with the given characteristics is equal to 74 $\mathrm{kPa}$.

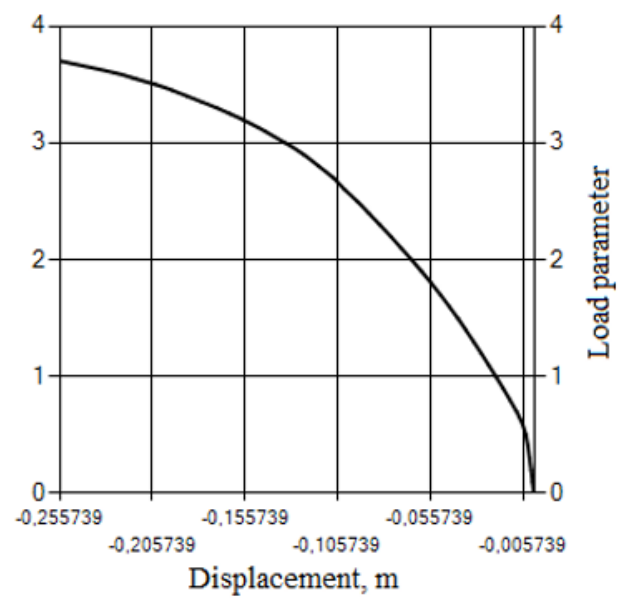

Fig. 5. The load-displacemen curve for initial version of slab, $q_{\lim }=74,0 \mathrm{kPA}$.

When the slab was reinforced at the stage of operation with the two layers of composite fabric, the behavior of the structure was described by the load-displacement curve shown in figure 6. It is seen from Figure 6, that when the structure is strengthened at the operation stage, the displacement gradients decrease, which is explained by an increase in the structure rigidity. The ultimate load have increased with the above strengthening to 78.6 $\mathrm{kPa}$. 


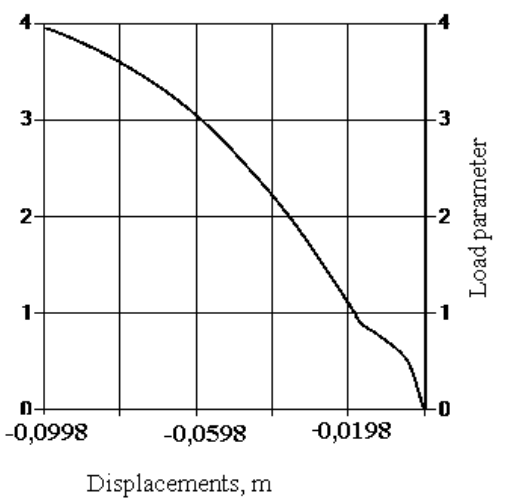

Fig. 6. The load-displacemen curve for the slab, strengthened by the two layers of composite fabric with the total thickness of $2 \mathrm{~mm}, q_{\text {lim }}=78,6 \mathrm{kPA}$.

At the second stage, cracks shown in figure 7 were initiated in the slab at the load equal to $20 \mathrm{kPa}$.

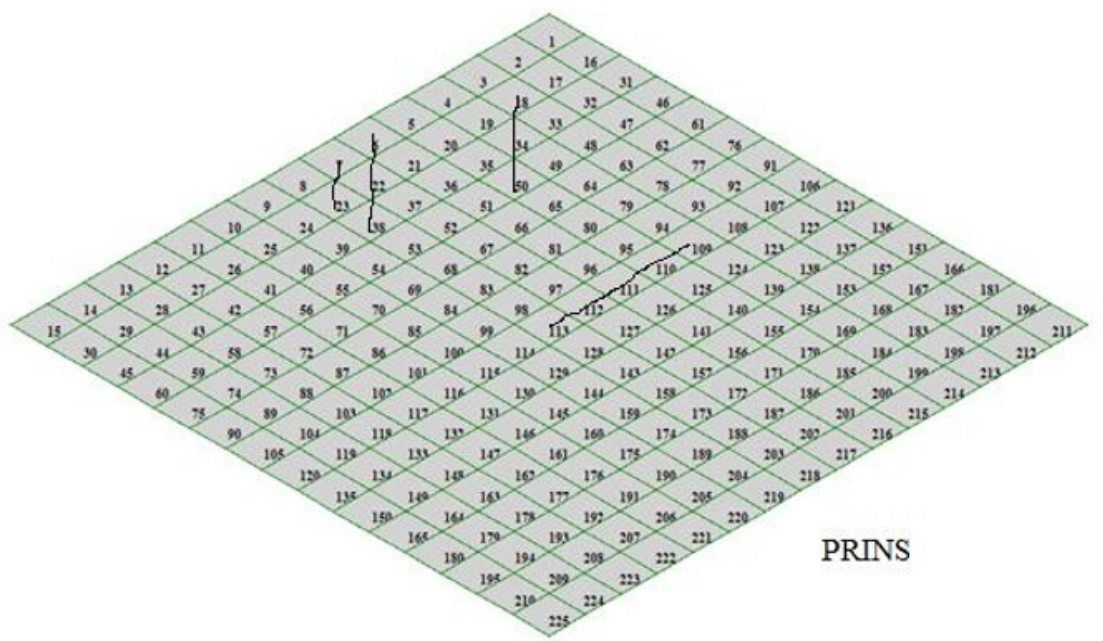

Fig. 7. Initiated cracks on the bottom surface of the slab.

Characteristics of cracks are given in table 3. The angle between the normal to the crack and the local $x$ axis of the element is indicated by the letter $\beta$.The calculation according to the PRINS program showed that when the cracks discribed above occurred, the ultimate load decreased to a value of $56 \mathrm{kPa}$ (figure 8). The crack formation on the bottom surface with the initial and initiated cracks under the load of $20 \mathrm{kPa}$ is shown in figure 9 
Table 3. The initiated cracks charackteristics.

\begin{tabular}{|c|c|c|c|c|c|}
\hline $\begin{array}{c}\text { Load } \\
\text { value } \\
\text { КПа) }\end{array}$ & $\begin{array}{l}\text { Group of } \\
\text { element } \\
\text { number }\end{array}$ & $\begin{array}{l}\text { Element } \\
\text { number }\end{array}$ & $\begin{array}{l}\text { Specifier } \\
\text { of surface }\end{array}$ & $\begin{array}{l}\text { Crack } \\
\text { depth } \\
(\mathrm{cm})\end{array}$ & $\begin{array}{l}\text { Angle } \\
\beta\end{array}$ \\
\hline 20 & 1 & 6 & 0 & 20 & -45 \\
\hline 20 & 1 & 7 & 0 & 20 & -45 \\
\hline 20 & 1 & 22 & 0 & 20 & -45 \\
\hline 20 & 1 & 23 & 0 & 20 & -45 \\
\hline 20 & 1 & 38 & 0 & 20 & -45 \\
\hline 20 & 1 & 18 & 0 & 22 & -45 \\
\hline 20 & 1 & 34 & 0 & 22 & -45 \\
\hline 20 & 1 & 50 & 0 & 22 & -45 \\
\hline 20 & 1 & 109 & 0 & 22 & 90 \\
\hline 20 & 1 & 110 & 0 & 22 & 90 \\
\hline 20 & 1 & 111 & 0 & 22 & 90 \\
\hline 20 & 1 & 112 & 0 & 22 & 90 \\
\hline 20 & 1 & 113 & 0 & 22 & 90 \\
\hline
\end{tabular}

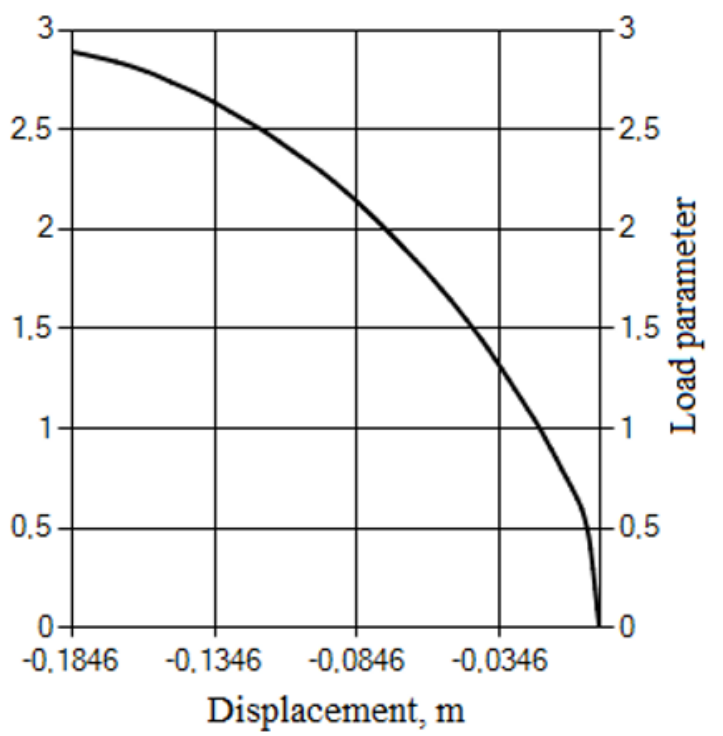

Fig. 8. The load-displacement curve for the slab with the cracks arising at the operation stage. 


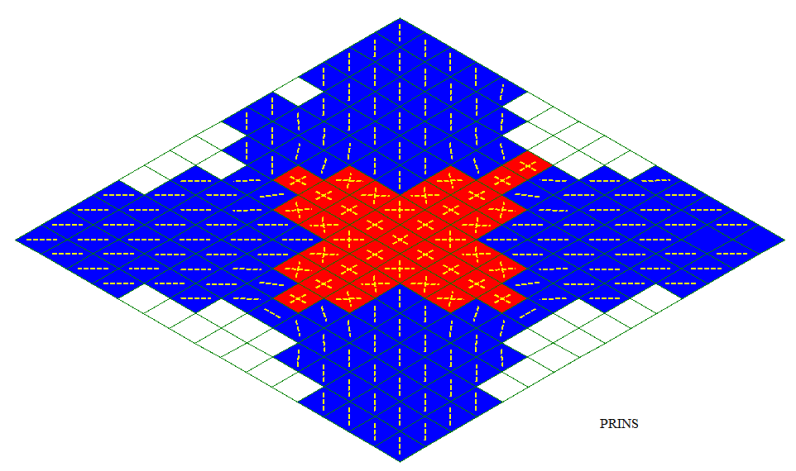

Fig. 9. Initial and initiated cracks at the load of $20 \mathrm{kPa}$.

The result of the calculation of the slab with initiated cracks after reinforcement with two layers of composite fabric is shown in figure 10 as a load-desplacement curve. The maximum load have increased to $67.2 \mathrm{kPa}$.

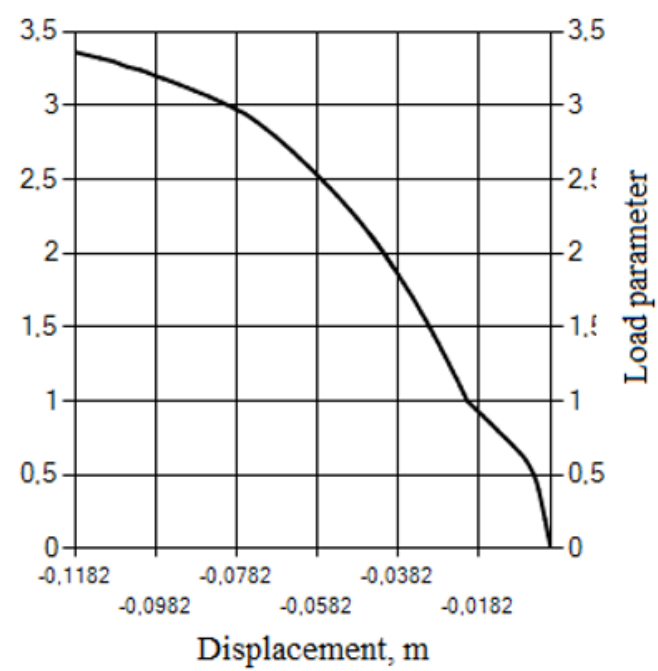

Fig. 10. The load displacement curve for the slab with initiated cracks after reinforcement.

\section{Conclusion}

The algorithm developed in this article and implemented in the PRINS program makes it possible to calculate reinforced concrete slabs with internal and external reinforcement, taking into account the actual loading history, up to destruction. This is especially important when the works related to the repair or reconstruction of structures are carrying out without their dismantling. The PRINS program allows us to estimate the bearing capacity of reinforced concrete slabs in their initial state, to find the ultimate factor of safety in the event of defects in the form of cracks and to select the necessary reinforcement by calculation. The use of the PRINS program at the stage of development of a project for the reconstruction or repair of reinforced concrete structures will give to civil engineers the opportunity to choose the strategy for future works more sensible and to avoid unnecessary waste of time and material resources. 


\section{References}

1. E Kal'yanova 2014 Stroitel'stvo No 8 pp. 54-58

2. A Cardoline 2003 Carbon Fibre Reinforced Polymers for Strengthening of Structural Elements ( Division of Structural Engineering, Department of Civil and Mining Engineering, Lulea University of Technology, Sweden

3. Externally bonded FPR reinforcement for RC structures 2001 fib Bulletin 14

4. FPR reinforcement in RC structures 2007 fib Bulletin 40

5. Model Code 2010, Final Draft 2012 fib Bulletin 65

6. V CHernyavskij, E Aksel'rod 2004 Promyshlennoe i grazhdanskoe stroitel'stvo № 3 pp. 37-38

7. N Paranicheva, T Nazmeeva 2010 Inzhenerno-stroitel'nyj zhurnal № 2 pp. 19-22

8. Rukovodstvo po remontu betonnyh $i$ zhelezobetonnyh konstrukcij i gidrotekhnicheskih sooruzhenij atomnyh stancij 2012 (OAO «Koncern Rosehnergoatom» Moskva)

9. Vosstanovlenie $i$ povyshenie nesushchej sposobnosti zhelezobetonnyh plit perekrytij $i$ pokrytij 2016 (STO NOSTROJ/NOP 2.7.141-2014 Izdanie oficial'noe Moskva)

10. S Shihada, Y Oida 2013 International Journal of Recent Development in Engineering and Technology 1 Issue 1 pp. 1-5

11. Rekomendacii po primeneniyu tkanevyh kompozicionnyh materialov pri remonte zhelezobetonnyh konstrukcij mostovyh sooruzhenij 2013 (Federal'noe Dorozhnoe Agentstvo Rosavtodor Moskva)

12. Rukovodstvo po usileniyu zhelezobetonnyh konstrukcij kompozitnymi materialami 2012 (NIIZHB, Moskva )

13.Z Ismail 2012 Archives of Civil Engineering 58 Issue 2, pp. 135-151

14. V Agapov Metod konechnyih elementov $v$ statike, dinamike i ustoychivosti konstruktsiy 2005 (Moscow: Izd-vo ASV)

15. V Agapov 2018 IPICSE-2018 DOI: https://doi.org/10.1051/matecconf/201825104035

16. POSOBIE PO PROEKTIROVANIYU BETONNYH I ZHELEZOBETONNYH KONSTRUKCIJ IZ TYAZHELOGO BETONA BEZ PREDVARITEL'NOGO NAPRYAZHENIYA ARMATURY ( $k$ SP 52-101-2003) 2005 (Moskva) 